\title{
An Assessment of Property Tax Administration in Edo State, Nigeria
}

\author{
Toju . F. Balogun \\ Department of Geography and Regional Planning, University of Benin, P.M.B.1154, Benin City, Nigeria.
}

Received: 2017-01-31 Accapted: 2018-08-01

Key words:

Internally generated revenue; property tax;

buoyancy;

valuation;

tax evasion

\begin{abstract}
Abstaract The mode of administration of property tax determines its buoyancy. The study utilizes key informant method to examine the mode of operation of Edo State Land Use Charge. The study observes that property tax revenue mobilization in Benin Metropolis is ineffective due to unsystematic tax administration procedure employed by Land Use Charge Department. The study shows that inadequate personnel, public contempt, limited coverage of the tax base and shrouded valuation method are major problems of the Land Use Charge in Benin metropolis. It also reveals that the current property tax administration will not appreciably enhance the internally generated revenue except the mode of operation is reformed. To overcome these challenges it is recommended among others that the implementation of modern and transparent assessment methods for real estate utilizing remote sensing and GIS integrated with computer-assisted mass appraisal (CAMA) be incorporated through a public-involved debate on property tax reform.
\end{abstract}

\section{Introduction}

The Local Government is expected to generate revenue from within to supplement the federal allocation accruing from petroleum resources. This is particularly required now that the revenue from petroleum has gone down due to the fall in oil price and coupled with the dwindling economy (Oni and Ajani, 2011). Among the sources of internally generated revenue approved (Otubu, 2018) which is equitable, certain, unhidden and can be monitored is property tax (Corker and Nieminen, 2001). Property tax is an important local revenue source that is often underused as a source for financing local expenditures. According to Kelly (2003) property taxes account for about $40-80$ percent of local government revenues, except in developing countries where the property tax may generate a maximum of 40 percent of local government revenues. For example, Ghana property tax accounts for about $14 \%$ of the total revenues of local assemblies, an average of about $6 \%$ of total local revenue in local councils in Sierra Leone, and less than 10\% in The Gambia (Fjeldstad, Ali and Goodfellow, 2017) .Thus, the amount generated from this source is very small compared to the potentials of property tax. Although property tax has great potentials yet it is faced with the problem of ineffectiveness and unreliability which seriously limit its ability to generate enough revenue. In particular, weak administration and technical limitation hinder the extent to which local government can tap on an expanding tax base and enforcing compliance to property taxation.

Although the focus of many state governments is currently on property tax, review of property tax administration in various states in Nigeria however shows varying degree of challenges militating against its success as a source of internally generated revenue. For example, Babatunde and Sunday (2008) in a study conducted in Minna, Niger state, observed that the land based taxes levied in the state are stamp duty and business premises registration. They reported that the major problem of property tax in Niger State is lack of political will to support the assessment and collection of property tax. In Akwa Ibom State, Ndehedehe and Kolawole (2012) in their study reported that land administration is carried out using hard copy revenue data either in the form of maps or descriptive documents. There is no documentary evidence of title for up to $80 \%$ of the parcels in Akwa Ibom state. Besides, less than $10 \%$ of the state is covered by cadastral survey in hard copy form. Out of 23 Local Government Areas of Kaduna State, according to Ishaya, Dabo and Makama (2012), only three have tenement rating units. The reason for this was that the cost of collection of the tenement rates was higher than the revenue generated from the exercise. If the cost of administering the properties becomes higher than the generated income then the rating is uneconomical. Added to this was the corrupt practice of the revenue staff.

In Bauchi state, Muhammad and Ishiaku (2013) identified lack of political will, inadequate records of taxable properties, unpopularity of the tax, inadequacy/ lack of skilled personnel and corrupt practices of officials as the major challenges militating against the success of property tax administration. Added to this was that most taxable properties are owned by the ruling class which made it difficult to effect compliance. Oluwadare and Ojo (2014) in their study in Olorunda Local Government Area of Osun State observe that inadequate knowledge of spatial distribution of properties and the haphazard manner in which the property tax record is kept contributed to the huge amount of revenue being lost by the government. Their study further revealed that only financial institutions 
are up-to-date in the payment of property tax probably due to the fear of losing customers in case they are prosecuted. The study concluded that government can meet up with its financial obligations by establishing GIS Unit for accurate management of property tax records.

In 2012, Edo State obtained a loan of N7.5 billion from the World Bank. Out of which the government proposed to computerize the Ministry of Lands and Surveys and create the Edo State Geographical Information System (EGIS) that will be one-stop system for all land transactions. Although GIS laboratory exist but data on property characteristics and ownership needed for property tax administration are lacking. Available hardcopy cadastral map covers only the Government Reservation Area (GRA). In spite of these inadequacies Edo State government went ahead to sign into law Land Use Charge in 2012. Only Lagos State and Federal Capital Territory (FCT) have success stories. In Lagos, all land taxes were subsumed under Land Use Charge and land documents were electronically converted to create digital database of properties. In the case of FCT, cadastral coverage exists right from the creation of FCT. Lagos and FCT have organized property information needed to administer property tax. FCT is yet to commence property tax but for Lagos study showed that there is a positive relationship between internally generated revenue and infrastructural development (Adesoji and Chike, 2013).

The above review agrees with UN (2013) observation that revenue buoyancy depends largely on improved administration. A common denominator in all the failing states is that they all suffer from weak institutional framework for administering property tax. This is a fall out from lack of clear policy on property tax management. Although the Federal Government granted the state governments authority to collect property tax there was however no specific guideline on property tax management that will provide direction. These identified challenges can be addressed through policy reform. This study assesses the current practice of property tax in Edo State with a view to suggesting policy review where necessary and the adoption of efficient method which will improve the buoyancy of property tax to meet the growing needs of the city for infrastructure development.

\section{Methods}

Benin, a traditional city and the state capital of Edo State is geographically located within the Latitudes $6^{\circ} 10^{\prime}$ and $6^{\circ} 30^{\prime}$ North of the Equator and Longitude $5^{\circ} 30^{\prime}$ and $5^{\circ} 45^{\prime}$ East of the Greenwich Meridian. Benin City comprises of Egor, Oredo, Ikpoba-Okha, and part of Ovia North East Local Government Areas with a projected populations of $1,682,158$. Benin is an administrative / civil service city (Onokerhoraye, 1978). Major economic investment in Benin is real estate development which account for the rapid urban expansion (Balogun, 2013) and the need for government to harness this resources for internally generated revenue. Key informant interview was utilized to obtain information from the Ministry of Lands and Survey. This method was used because land use charge is a recent development in Edo State. There are limited published documents that one can rely on. Also because there are key informants who were accessible and because of their involvement they have in-depth knowledge of the issue. To ensure adequate representation of opinions, enough informants which involved seventeen staff (17) of the Land and Survey were interviewed. It was felt that additional informant was no longer necessary as additional interview was no longer yielding new insight to the study. In addition, structured questionnaire was administered to 333 property owners that were systematically selected from the study area.

\section{Property tax administration in Benin City}

The land based taxes charged in Benin City before the 2012 Land Use Charge Law of Edo State include ground rent, tenement rate and land use charge. The Land Use Charge Law was signed into law to make provision for the consolidation of all land-based rates and charges payable in Edo State into a single charge to be called land use charge. The bill seeks to generate and increase the internally generated revenue of the state. Thus the main purpose of the bill is to fast track development of the state. The statutory process of the tax system sets out policy choices clearly by setting the tax rate, defining the assessment procedures, exemptions and setting the guideline for responding to assessment appeals. The bill allows taxation of four categories of property including residential property land (size in excess of 100 feet by 50 feet $(30 \mathrm{~m}$ by $15 \mathrm{~m})$ ), commercial /residential property, commercial property and industrial/ manufacturing property. Residential property with shops in them and blocks of four flats would be taxed under the commercial/residential property category.

The Law places the responsibility for payment on the owner of an assessed property, and such person is liable to pay Land Use Charge in respect of the assessed property. There are sanctions for a variety of infractions on the law. Accordingly, any person who refuses, or neglects to comply, prevents, hinder or obstruct an assessor in the course of his lawful duty or with intent to obliterate relevant records or damages or destroys a property, identification plaque, or any property or building has committed an offence and shall be liable on summary, conviction to a fine of N100,000.00 in the case of an individual or N500,000.00 in the case of a corporate body or to a term of imprisonment for a period of three months or both fine and imprisonment.

\section{Lack of fiscal cadastral}

Fiscal cadastral contains the spatial data 
information such as parcel size, location, use, ownership e.t.c. that are needed to create database for property tax administration. Non spatial aspects of the information are collected on the field. The visual characteristics of the fiscal cadastral serve as aids in the collection of the non-spatial data. Hence, Ndehedehe and Kolawole (2012) observe that cadastral records form the input to assess land revenue and general land administration. In Benin City only Government Reservation Area (GRA) and Edo Development Property Authority Estates have cadastral coverage. These, put together are less than 5\% of the area of Benin City. This is a common phenomenon in most developing countries as enunciated by previous workers like Vincent and Gosselin, (2012) who observed that land administration in most countries involves a systematic approach to providing data infrastructure to manage the normal processes related to delivering land and managing land markets. Yet without property information, property assessment is problematic and will lead to loss of reven

\section{Result and Discussion}

Property enumeration method in Benin Metropolis

Key informant interviews scheduled with the staff of Land Use Charge Department revealed that the current mode of operation used by the Land Use Charge Department is that lucrative areas of the city are identified, field officer are then sent out to these target areas to carry out property assessment. The targeted areas are the commercial corridors (mainly along the major arterial roads). The targeted areas that have been assessed are Government Reservation Area (GRA), Akpakpava Road, Sapele Roads, Forestry Road, Mission Road, Ring Road, Airport Road and all the banks in Benin Metropolis. A cartographic representation of these areas is shown in Figure 1. The assessment is expected to progressively move to other parts of the metropolis. Figure 2 is the assessment form used by the field officer for property assessment. Information

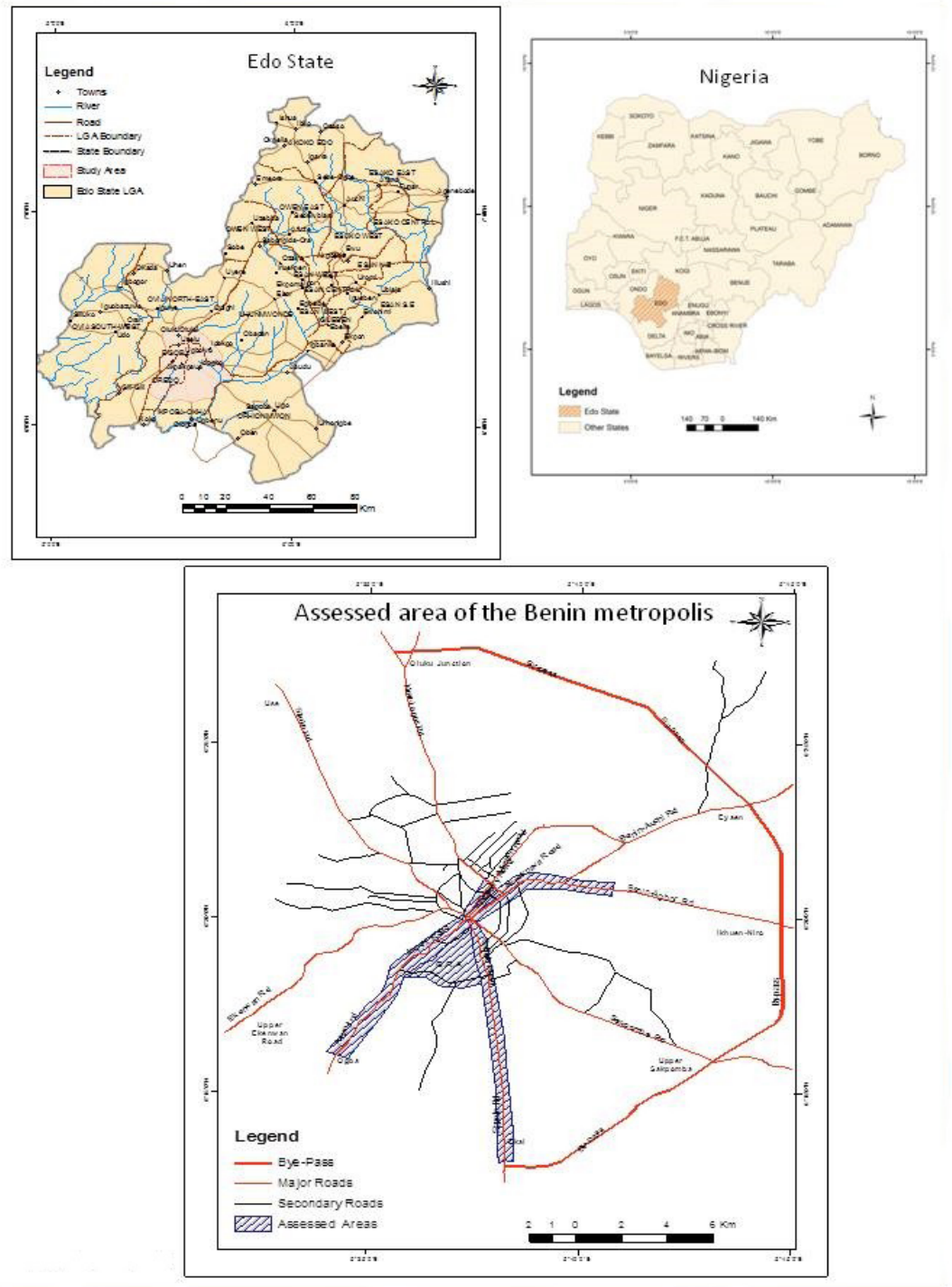

Figure 1. Assessed areas of the metropolis. 
generated is handed over to the Estate Valuers. The Estate Valuers values the property based on the second hand information. On the basis of this, bills are sent by hand delivery through the field officers to property owners who in turn pay to the bank.

This method raises a lot of questions. First, the enumeration method is grossly inadequate because it is unsystematic in nature and fraught with loopholes. For example not all the properties within the targeted areas are assessed even when they are not classified as exempted properties.

There will be omission of properties either intentional or unintentional. The implication is that many properties will be left unaccounted for thus reducing the tax base and leading to loss of revenue to the government. Some informant felt that the method could create ill feelings among the property owners who were taxed as they may consider it as selective taxation. Such feelings could reduce voluntary compliance. It was also felt that with this method monitoring will be difficult to carry out since it is selective.

This observation is in line with Collier et al (2017) who observed that it can lead to significant loss of municipal revenue and suggested the use of geographic information systems (GIS), digital maps, and aerial photographs to identify plots of land and the structures on these plots can be quicker than by traditional methods of official site visits. Hargeisa, Somaliland was cited as an example where land ownership registration was virtually nonexistent in 2005. With assistance from UN-HABITAT, the local government in Hargeisa developed basic cadasters using satellite data and surveys to collect data on physical characteristics of properties and the occupier(s) of those properties. Within eight months properties registered for taxation increased from 15,850 to 59,000 and revenue increased by $248 \%$ (Collier et al, 2017).

There are streets without name and houses without number especially in the developing areas. Delivery of bills is a serious challenge especially when enumerator that assessed the area is not the one distributing the bill. Other challenges include irregular distribution of bill and inability to trace addresses due to change of ownerships. It is on this ground that Collier et al, (2017) suggested that automation of billing and computerised payment systems can be key to improving tax collection by allowing for efficient monitoring and collection of payments and reducing opportunities for corruption.

\section{Data format}

Properties enumerated and assessed in the field were not geo-referenced. The assessors had no GPS or map to work with. The assessment form, Figure 2, did not provide space for GPS reading. To bring the enumerated properties into a GIS database in the future will require going back to the field to repeat the same procedure. This will amount to waste of human resources and public fund. Currently, the Land Use Charge Department does not have any GIS expert as a staff to guide them, although there is a well equipped GIS Unit in the Town Planning Department within the same office complex.

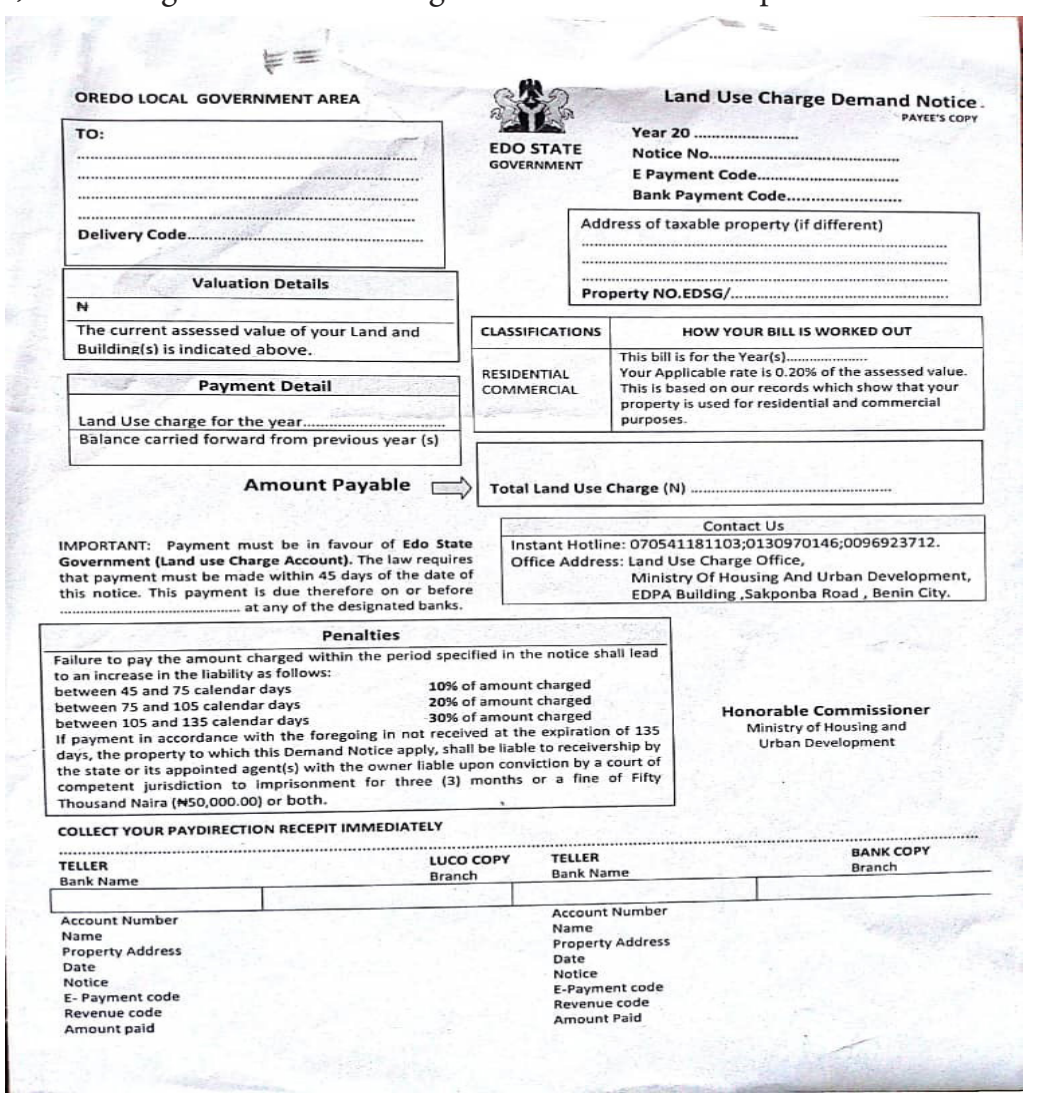

Figure 2. Land use charge assessment form 


\section{Inadequate preparation}

Important preparation that could aid in the process of property taxation such as streets naming, house numbering and property database creation were not done prior to the commencement of the property tax administration. Even now there are no plans on ground for these. Without these, it becomes difficult to bring all the properties into the tax database. Many of the properties will be omitted and will lead to loss of revenue to the government. In addition bills distribution becomes problematic. It is expected that before implementation stage there should have been institutional arrangement put in place to carry out a pilot study. During such period, loophole for tax evasion and system errors are checked and corrected. None of these was done before embarking on the implementation. The low level of preparedness of Land Use Charge Department may perhaps be partly responsible for the low buoyancy of property tax. Hence Abiola and Asiweh (2012) observed that the failure of property tax to yield appreciable revenue is not valuation but is the pure responsibility of tax administration.

\section{Operationalization of valuation model}

This is the formula adopted by Edo State Land Use Charge Department for property valuation

$\mathrm{LUC}=\mathrm{M} \times\{(\mathrm{LA} \times \mathrm{LV})+(\mathrm{BA} \times \mathrm{BV} \times \mathrm{PCR})\}$.

Where, LUC = annual amount of land use charge in Naira

$\mathrm{M}=$ the annual charge rate expressed as a percentage of the assessed value of the property and which may, at this State Government's discretion, vary between owner occupied residential property and commercial (revenue generating) property.

$\mathrm{LA}=$ the area of the land parcel in square metres.

$\mathrm{LV}=$ the average value of a land parcel in the neighbourhood, per square metre in Naira.

$\mathrm{BA}=$ the total developed floor area of building on the plot of land in square metres, or the total floor area of apartment unit in a building where apartment has a separate ownership title.

$\mathrm{BV}=$ the average value of medium quality building in the neighbourhood, per square metre in Naira

$\mathrm{PCR}=$ the property code rate for the building and which accounts for the building being of higher or lower value than the average buildings in the neighbourhood and which also accounts for the degree of completion of construction of the building.

$(\mathrm{LA} \times \mathrm{LV})+(\mathrm{BA} \times \mathrm{BV} \times \mathrm{PCR})=$ the assessed value of the property
The Estate surveyors among the key informants were asked to explain how to operatinalize the property tax model. None of them could explain how it is done. According to them, they are involved in the property assessment but the departmental head does the calculation. What happens if the Head goes on leave or retires? There is no contingency plan for when the Head would go on leave or retire. Currently the assessment is being carried out in some targeted areas of the metropolis. When the whole city is involved, manual calculation will be cumbersome. Besides, if the Estate Surveyors in the Land Use Charge Department could not explain the formula, it is unlikely that the property owners will be able to do so. A formula that property owners cannot crosscheck themselves may likely generate a lot of tax appeal cases. Lack of understanding on how the tax is levied may affect tax payers' confidence. Hence, World Bank, (2014) and Collier et al (2017) opined that Area-based tax value assessment offers the simplest form of standardized assessment of land and/or property, increased transparency of the tax system and made property tax administration easier.

\section{Inadequate staffing}

The adequacy of staff strength was considered and result shows that the quality of staff is high but the quantity is grossly inadequate considering the volume of work they have to do. The manpower composition consist of 5 registered Estate Surveyors and Valuer, 14 unregistered Estate Surveyors and valuer and 5 secretariat staff. The total staff strength is 24 in number. Their jobs involve property survey, property assessment, bill distribution and collection, monitoring and enforcement of compliance (through the assistance of mobile court). Since manual method is the mode of operation this staff strength is grossly inadequate. Inadequate personnel in terms of quantity, quality and composition to administer tax system can negatively affect efficiency and service performance. This can leads to under-valuation thus reducing government's revenue. The Department is aware that with the current staff strength it may be difficult to cope with the demand of the work. In spite of this, the government is not willing to employ more hands rather the Department planned to involve independent valuers in the near future. The unwillingness on the part of the government to employ more hands for effective delivery of their mandate gave the impression that the department is not enjoying political support. Otherwise the State Government ought to throw its weight behind the Land Use Charge Department in terms of financial support in other to deliver more internally generated revenue for the government.

\section{Public opinion about land use charge}

There was a serious protest when land use charge was signed to law. Because of this, property owners were asked about their opinion on the property tax. In 
Figure 3 , only $2 \%$ of the respondents are of the opinion that property tax is costly while another $2 \%$ believe that it will lead to increase in rent; $20 \%$ are of the view that it will not work in Benin metropolis because of corrupt practices; $6 \%$ had the feeling that it will lead to reduction in housing supply. As many as $35 \%$ did not see it as a good development, $1 \%$ are of the opinion that it should be limited to only commercial land use only, $5 \%$ are of the view that property tax amount to over taxation while $11 \%$ decline response to the question. Only $18 \%$ believe that property tax is used for development.

\section{Unwillingness among property owners to pay property tax}

Property owners were asked if they were willing to pay property tax. Out of the 333 respondents $74 \%$ were unwilling to pay property tax. $24 \%$ were willing to pay while $2 \%$ were undecided. The high percentage of unwilling to pay is an indication that the tax is unpopular. This result is in agreement with FAO (2002) who observes that no tax is popular. It is unpopular perhaps because this is the only tax that they 'see' (USAID, 2010). Other taxes are deducted from their income or are included in the price of goods purchased/ acquired. Those that indicated unwillingness to pay were asked to give reasons for their lack of interest. Two major reasons were given for not willing to pay property tax. As high as $68 \%$ of the respondents were of the view that they could not link the tax collected with the service provided while $32 \%$ were of the view that it amounted to double taxation since they have paid tax at their places of work and also paid for plan approval before the commencement of the building project.

The implication of this is that public confidence in the tax system is essential for the success of property taxation (Bahl, 2009; Kundu and Ghosh, 2011). It may also imply that if the public is able to see a direct link between the tax collected and the services provided there may be improvement in the level of acceptance
(UN-Habitat, 2013). In other words satisfactory service to the taxpayers could encourage voluntary compliance (USAID, 2013). Hence local governments should embark on relevant projects and programmes that touch on the life of the people as this will make the residents feel happy and have the urge to pay their rate liabilities whenever demand notices are served on them (Olatunji and Ayodele,(2017).

This finding also implies inadequate public sensitization. Lack of adequate information has the tendency to lower the tax payers' compliance. Considering the fact that no one wants to pay tax, it is expected that the government will sensitize the public towards accepting the property tax law. Tax knowledge and education can have positive effect on level of tax compliance on real estate investors. The tax payer needed to be given tax compliance education because public acceptance is the cumulative effect of many things, including amount of the tax, ease of tax payment, benefits received, openness, and perceived fairness (USAID, 2010).This can be done through public information campaigns, social media platforms and via the internet. Because some prospective property rate payers abscond from payment due to ignorance, meaningful enlightenment campaign will reduce the aggression which the public exhibit during rating assessment and rate collection (Wambai and Hanga, 2013).

\section{Tax Collection, enforcement and appeals}

Increase tax revenue is a function of effective enforcement strategy which is the responsibility of tax administrators. In every property tax administration, the revenue statute provides powers of enforcement in cases of non-payment. The study reveals that in Benin metropolis (1) bills are distributed through the field officers (2) property owners in Benin metropolis are expected to pay their bills to designated banks in the metropolis and (3) in the event of refusal to pay; Edo

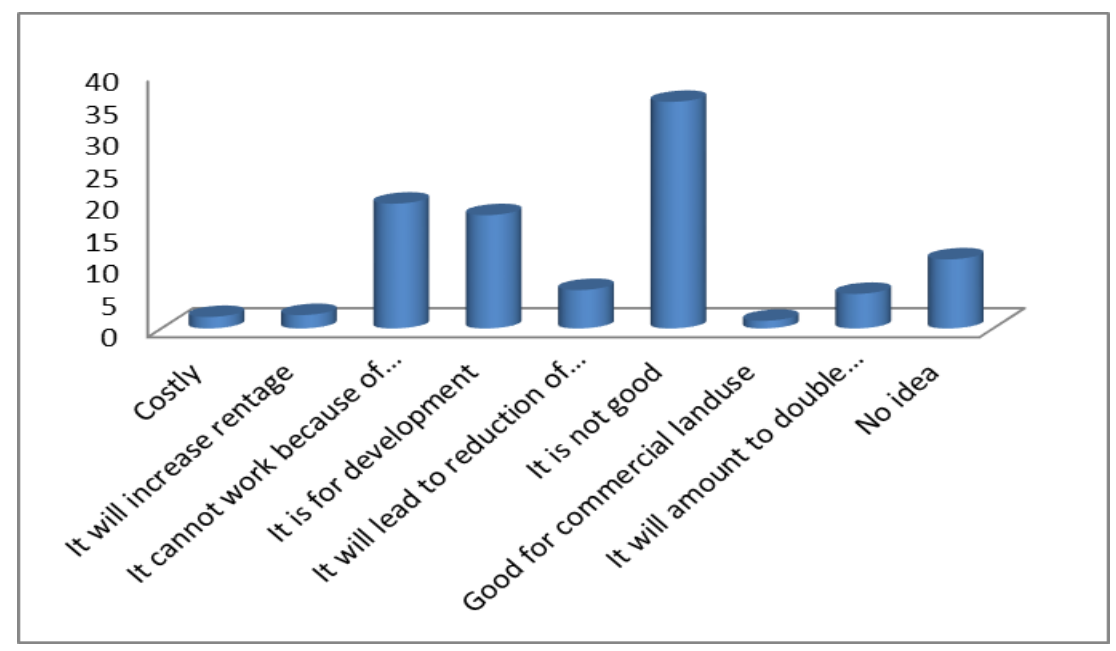

Figure 3. Public opinion about land use charge 
State Land Use Charge uses task force. Section 5.4.2 and 5.4.3 of the Land Use Charge Law spelt out sanctions and penalties/liabilities for defaulters. Assessment appeal distinguishes property taxes from other forms of taxes (income, consumption, sales, etc) by providing property owners with an opportunity to meet with the assessor, to inquire about the various factors considered in the assessment of their properties (Kundu and Ghosh, 2011). If dissatisfaction arises, owners take an appeal through a tribunal, local court or the state (hierarchical steps), where an appeal panel will determine whether or not the assessment should apply. Edo State has a task force and mobile court that handles such appeal cases. How effective this unit is yet to tested

\section{Property tax Reform}

The study revealed the following challenges: unpopularity of the tax, lack of sensitization of the public, inadequate preparation, selective coverage/ taxation, hand delivery of tax bills, inadequacy of skilled personnel, un-simplified tax model, lack of georeferencing of data collected and lack of political will. These are enough to lower property tax buoyancy. The present deficiencies occur on account of the present assessment system and poor administrative and information system currently in place. They are also indicators that there is a need for tax administration reform in Edo State to enhance service delivery capacity. Olaleye et al., (2005), UN-Habitat-GLTN, (2011), Boamah, (2013) and Oluwadare and Ojo, (2014) are of the view that successful property tax reform must be comprehensive, covering all aspects of property tax administration namely, coverage, valuation, collection, enforcement, remittance and taxpayer service. To effectively do this, barriers to reform that are preventing progress, and will continue to do so unless they are explicitly factored into dialogue and policy, and into programme design should be considered (DFID, 2017)

There are different areas calling for reform. The first area identified for a reform is the need for update of property record without which tax administration is difficult. Incomplete property record will reduce the tax base and lead to loss of revenue to the government. Considering the cost and time involved this may not be easily accomplished except there is the political will.The pay off on the long run is high if carried out

The second area identified for reform is the manual method of operation. The current manual method of property tax administration is cumbersome, ineffective, and inefficient and it is incapable of meeting up with the numerous challenges posed as a result of the demands for parcel or property related information. The manual system is often characterized by omissions and discrepancies. The present method will not allow the detection of tax loopholes which can be unduly exploited by tax payers in reducing their tax liabilities; and to make appropriate measures to block the loopholes. For example, in terms of coverage, the current method will not permit the total property to be brought into the tax base as most property will be left unaccounted for. Besides, it will be difficult to know the total number of properties that are taxable, and difficult for government to know the expected revenue from Land Use Charge. This alone is enough to discourage the political support. In addition, the manual method is a fertile ground for corrupt practices by the officials. Whereas the introduction of modern technology proved effective in Arusha City Council in Tanzania (World Bank, 2014, Fjeldstad, Ali and Goodfellow, 2017) in eliminating these challenges and increasing revenue generation.

The landuse charge law gives room for tax evasion. For example the tax law exempted residential building on a plot of land that is not more than $100 \mathrm{ft}$ by $50 \mathrm{ft}$ $(30 \mathrm{~m}$ by $15 \mathrm{~m})$. An estate developer who has one residential property on $100 \mathrm{ft}$ by $100 \mathrm{ft}(30 \mathrm{~m}$ by $30 \mathrm{~m})$ is expected to pay property tax otherwise he/she will be liable. Another estate developer who is out to evade tax will rather than buying a plot of $100 \mathrm{ft}$ by $100 \mathrm{ft}$ ( $30 \mathrm{~m}$ by $30 \mathrm{~m}$ ) or more in one place may decide to buy $100 \mathrm{ft}$ by $50 \mathrm{ft}$ in several places within the metropolis, develop residential buildings on them and be making his money quietly without paying property tax and yet is not guilty of any offence according to the property tax law. There is no social justice here. To avoid this type of situation the government should specify the number of $100 \mathrm{ft}$ by $50 \mathrm{ft}(30 \mathrm{~m}$ by $15 \mathrm{~m})$ own by an individual that will be tax free. Anything in excess of that should attract tax. This is achievable only in an environment where there is proper record keeping especially in a GIS environment where every property has an ID that is linked to owners' name, passport photograph and property approved plan. Duplications of owners can easily be detected. Fjeldstad,Ali and Goodfellow (2017) observed that such reform led to a fourteen-fold increase in the number of enumerated properties in Lagos state within three years from 45,000 in 2007 to 635,000 in 2010.

\section{Conclusion}

In this study, reasons for inefficiency in property tax administration in Edo State have been identified. Against the backdrop of the size of Benin metropolis, the dynamic nature of properties especially with the absence of cadastral map and incomplete land registry record and with the associated urgency and accuracy demanded in property tax administration, GIS and Remote Sensing method that is amenable to constant updating and flexibility is suggested for the creation of a complete up-to-date property tax database. In a GIS database, each property has an identification code which facilitates the process of crosschecking for defaulters. With such database in place it will be possible to know the total properties, the exempted properties and the estimated revenue for the current year. GIS has 
the capacity and capability of being used to easily and accurately capture, edit, store, retrieve, update, query, manipulate, analyze, display, and output property data in various formats in a timely and cost effective manner.

Grass root support is more likely if taxpayers both feel that they are receiving adequate services for the property taxes that they pay and if they perceive that the process of taxing property is fair and accountable. This can take place when (1) there is transparency, (2) and enough sensitization and publicity of government project on which the tax is spent. Government has a lot to do in the area of public enlightenment if the investment in property tax administration is to yield appreciable result. Also public understanding of the benefits of property tax can go a long way in ensuring voluntary compliance. Therefore the government should create opportunity for the public to participate in the property tax debate, workshops and seminars.

Institutional capacity building is essential for effective property tax delivery. All the valuation officers should be trained on how to apply the land use charge formula. Remote Sensing and GIS integrated with computer-assisted mass appraisal is strongly suggested for use in Land Use Charge for database creation and processing for effectiveness and efficiency of service delivery. Staff should be trained in the use of these software.

The study observed that property tax revenue mobilization in Benin Metropolis is ineffective due to unsystematic tax administration procedure employed by Land Use Charge Department. The method gives room for omission of properties and tax invasion. The study shows that an inadequate property tax administration system, inadequate personnel, public contempt, limited coverage of the tax base and shrouded valuation method are major problems of the Land Use Charge in Benin metropolis. The study also revealed that the current property tax administration will not appreciably enhance the internally generated revenue except the mode of operation is reformed. To overcome these challenges it is recommended among others that the implementation of modern and transparent assessment methods for real estate utilizing remote sensing and GIS integrated with computer-assisted mass appraisal be incorporated through a public-involved debate on property tax reform. Professional staff in geospatial analysis and Estate Surveyors and Valuers should be employed in the Land Use Charge Department and trained in the use of these technologies.

\section{References}

Abiola, J. and Asiweh, M. (2012). Impact of Tax Administration on Government Revenue in a Developing Economy - A Case Study of Nigeria. International Journal of Business and Social Science Vol. 3 (8) [Special Issue - April

Adesoji, A. A. and Chike, F. O. (2013). The Effect of Internal Revenue Generation on Infrastructural Development. A study of Lagos State Internal Revenue Service Journal of
Educational and Social Researce Vol. 3 (2)

Balogun, T. F (2013). Emergence of Cooperative Society in Land Market in Nigeria. Pakistan Journal of Social Sciences Volume: 10 (3), 148-153 http://docsdrive.com/ pdfs/medwelljournals/pjssci/2013/148-153.pdf

Boamah, N. A. (2013). Constraints on Property Rating in the Offinso South Municipality of Ghana. Commonwealth Journal of Local Governance Issue 13/14. http://epress. lib.uts.edu.au/ojs/index.php/cjlg

Collier, P., Glaeser, E., Venables, T., Manwaring, P and Blake, M. (2017). Land and property taxes: Exploiting untapped municipal revenues. Policy brief.

Corker, I. and Nieminen, J. (2001). Improving Municipal Cash Flow - Systematic Land Information Management International Conference on Spatial Information for Sustainable Development Nairobi, Kenya 2-5 October

DFID (2017). Optimising Internally Generated Revenue in Nigeria Leap: High-Level Policy Dialogue Supplement to a Milestone PO7999

FAO (2002).Rural Property Tax Systems in Central and Eastern Europe.FAO Land Tenure Studies 5. www.fao. org/docrep/005/Y4313E/Y4313E00.HTM

Fjeldstad, O., Ali, M and Goodfellow, T. (2017). Taxing the urban boom: Property taxation in Africa. CMI INSIGHT 1.

Kelly, R. (2003). Property Taxation in Indonesia: Challenges from Decentralisation. Lincoln Institute Product Code: WP03RK1

Ndehedehe. C and Kolawole. B. (2012). Principles and Practice of Land Management and Administration in Akwa Ibom State. Journal of Environmental Science and Resources Management Volume 4 www.cenresin.org

Olaleye, J. B., Hamid-Mosaku, A. I and Idowu, S. O (2005). Geographic Information Systems (GIS) for Tenement Rate Administration: A case study of Eti-Osa Local Government in Lagos State. First National Seminar on the Application of Geographic Information System (GIS) on Local Government Administration for Efficiency and Good Governance. Abuja, Nigeria

Olatunji, O. C. and Ayodele, K. B. (2017). Impact of Information Technology on Tax Administration in Southwest, Nigeria Global Journal of Management and Business Research: D Accounting and Auditing Volume 17 (2) Version 1.0

Oluwadare, C .O. and Ojo, O. (2014). Database Creation for Tenement Rate Collection: The Role of GIS. Pacific Journal of Science and Technology. 15(1) 190-199.

Onokerhoraye, A. G. (1984). Social Services in Nigeria: An introduction. London, Kegan Paul International.

Oni, A. O. and Ajayi, C. A. (2011). Effects of Property Tax on Sustainable Housing Delivery in Lagos State, Nigeria www.ccsenet.org/jsd. Journal of Sustainable Development Vol. 4, (1).

Otubu, A. (2018). The Land Use Act and Equity Factor in Property Taxation in Nigeria. NAUJILJ 9 (1)

Kundu, D and Ghosh, D. (2011) Innovations in property taxation systems in India in: Innovative Land and Property Taxation. United Nations Human Settlements Program.94-110Nairobi, Kenya.www.unhabitat.org

UN-Habitat (2013). Property Tax Regimes in East Africa. The Global Union Economic Dialogue Series. United Nations Human Settlements Programme, Nairobi.www. unhabitat.org

USAID, (2010). Immovable Property Tax - An Innovative Tool to Increase Local Revenue. Local Governance Program in Albania. A publication of the United State Agency for International Development. http://pdf.usaid. gov/pdf_docs/PA00K4HR.pdf

USAID (2013). Detailed Guidelines for Improved Tax Administration in Latin America and the Caribbean. 
https://www.usaid.gov/sites/default/files/LAC TaxBook_Ch\%206\%20-\%20ENGLISH.pdf

Vincent, P. and Gosselin, C. (2012). Building Land Rights Infrastructures in Developing Countries: Advantages of High resolution Earth Observation Satellite Imagery as Main Source of Topographic information. Paper presented at the annual World Bank conference on Land and Poverty, The World Bank, Washington DC, April 2326http://www.landandpoverty.com/agenda/pdfs/paper/ vincent_full_paper.pdf

Wambai, U. S .K and Hanga B. Y. (2013). Taxation and Societal Development in Nigeria: Tackling Kano's Hidden Economy. International Journal of Academic Research in Business and Social Sciences. Vol. 3, (3) ISSN: 2222-6990 www.hrmars.com/journals

World Bank, (2014). Building Arusha: One City's Journey to Better Urban Services, Access and Quality of Life. http:// www.worldbank.org/en/news/feature/2014/08/12/ buildingarusha-one-citys-journey-to-better-urbanservices-access-andquality-of-life. 